Collection: Cost Action E29 Meeting 2008 - Istanbul (Turkey)

Future Monitoring and Research Needs for Forest Ecosystems

Guest Editor: Marcus Schaub (WSL, Birmensdorf, CH)

\title{
Means of combating forest dieback - EU support for maintaining forest health and vitality
}

\author{
Requardt A ${ }^{(1)}$, Schuck A ${ }^{(2)}$, Köhl M ${ }^{(1)}$
}

All EU Member States face economic and ecological losses due to forest damages. Thus, combating forest dieback, as for example caused by the effects of climate change, is a contribution to human safety and well-being and the sustainable development of Europe. At the EU level several efficient and well established policy instruments are developed and implemented, which contribute to the prevention, mitigation and control of forest dieback. The most important EU instruments in this context are the Rural Development Regulation (Council Regulation (EC) No 1257/1999, replaced by the Council Regulation (EC) No 1698/2005) and the Forest Focus Regulation (Council Regulation (EC) No 2152/2003, expired in 2006). The article reviews main EU policy and financial instruments and evaluates the feasibility of combating various causes of forest dieback in Europe.

Keywords: Forest dieback, EU policy, Financial support, Prevention, Mitigation, Control

\section{Introduction \\ Cooperation and support for sustainable forestry is part of the EU Forestry Strategy (1998; Council Resolution of $15^{\text {th }}$ of Decem- ber 1998 on a Forestry Strategy for the European Union - 1999/C 56/01) and the EU Forest Action Plan (2007-2011; COM (2006) 302 final: Communication from the Com- mission to the Council and the European Parliament of 15 June 2006 on an EU Forest Action Plan), aiming to ensure the protection and sustainable management and develop- ment of EU forests. The European Com- munity and its Member States have made several international commitments relating to the maintenance and protection of their forests, like within the UNFCCC (United}

(1) University of Hamburg, Institute for World Forestry, Leuschnerstr. 91, D-21031 Hamburg, Germany; (2) European Forest Institute, Torikatu 34, 80100 Joensuu, Finland

@, Aljoscha Requardt (a.requardt@holz.unihamburg.de)

Received: Mar 13, 2008 - Accepted: Dec 09, 2008

Citation: Requardt A, Schuck A, Köhl M, 2009. Means of combating forest dieback EU support for maintaining forest health and vitality. iForest 2: 38-42 [online: 2009-01-23] URL: http://www.sisef.it/iforest/show.php? id $=480$
Nations Framework Convention on Climate Change) and the Kyoto Protocol, the CBD (United Nations Convention on Biological Diversity) or the CCD (United Nations Convention to Combat Desertification).

In order to meet the aim of managing forests sustainably the health and vitality of forests is of high relevance. Forest health and vitality serves as an indicator for negative environmental impacts, which can in turn affect human welfare and the quality of life (MCPFE 2007). The EU Member States face economic and ecological losses due to forest damages. In recent years severe storms, fires, droughts, insect infestations and diseases have raised the attention of practitioners, research and policy makers alike. Thus combating forest dieback is seen as a contribution to both human safety and well-being and the sustainable development of Europe.

In order to effectively combat forest dieback in the EU, the magnitude and causes of forest dieback need to be assessed, efficient and coherent measures and strategies developed and implemented at both the community and national levels.

A feasibility study on "Means of combating forest dieback in the European Union" was initiated by the European Parliament demanding the European Commission to investigate the development of concrete proposals for preventing, mitigating and control forest dieback in the EU. The study was car- ried out by the Institute for World Forestry (Hamburg) and the European Forest Institute (Joensuu) in 2007 (Requardt et al. 2007 - the study report and its annex can be downloaded from EU DG ENV website: http://ec.europa.eu/environment/forests/fpoli cies.htm). The main objectives of the study were to:

- review different factors affecting forest dieback in the EU and their related causes,

- analyse and evaluate the effectiveness of available EU legislations and instruments to combat forest dieback in the EU and

- examine the possibilities for establishing a specialised entity for forest protection.

The primary task of the feasibility study was to analyse and evaluate the effectiveness of relevant EU legislations and instruments towards combating forest dieback in the EU. Most relevant EU instruments were analysed on how they address specific damaging agents and threats to forests in terms of prevention (targeted measures in threatened areas), mitigation (measures after damage occurrence in affected areas) and control (measures to monitor and manage total forest area).

\section{Results}

Importance of individual threats to forest ecosystem health and vitality

In addition to a comprehensive literature review on forest condition and the different causes of forest dieback in Europe, a survey was conducted in the EU Member States investigating the significance of damaging agents in EU27 forests. The results of the survey are summarised in Tab. 1 and indicate the importance of individual threats to forest ecosystem health and vitality within European regions. Insects, storm/windfall, and fire were regarded as the most serious threats in Central Europe, Western Europe and Southern Europe respectively. Regional differences in relation to damage types and intensity reflect the importance for particular instruments to prevent, mitigate and control various causes of forest dieback.

\section{Box 1 - Definition of forest dieback.}

"Forest dieback" is expressed as an umbrella term, which incorporates agents of all kinds that negatively affect the health, vitality and biodiversity of forests. Damages can be caused by biotic and abiotic agents or their combination thus resulting in mortality, or a significant loss of vitality, productivity or value of trees and other components of the forest ecosystem (after UNECE/FAO 2000). They can be of pure natural causes, be human induced or result from a combination of both. 
Nevertheless, the results of Tab. 1, can be interpreted from different angles. The five distinguished European regions include a different number of Member States, but are weighted equally when computing the total raking. Furthermore, the ranking does not take into account regional/national differences in forest coverage and wood production. Thus, Member States with a small amount of forest area and low wood production have the same impact on the total ranking, as Member States with a high amount of forest and high timber growth. This aspect leads to two basic points of views. If a country with a high amount of forest considers for example insects and browsing as the most important threats, these particular threats can be regarded of higher relevance and impact on European forests, than if a country with a small portion of forests considers for example fire or drought as the main threats. In contrast, countries with small amounts of forests might be much more adversely affected by threats given a high ranking as in Tab. 1. As the economic, ecologic and societal dimensions and relevance of forests differ between most European regions, the ranking of threats causing negative impacts on forests health and vitality in Europe needs to be distinguished and discussed from different perspectives. The different degree of ecologic, economic and societal impact, either at local, country and/or European level, need to be considered when evaluating the ranking of threats and their relevance on a European forest protection policy objectively.

Relevant instruments and programmes towards combating forest dieback in the $E U$

The responsibility for forestry policy lies within the EU Member States. Within the EU many horizontal and issue-driven policy initiatives that directly or indirectly have impact on the forest sector are developed. These influence national forest policies and actions and vice versa. Although the EU does not have competences in forestry policy - the Treaty establishing the European Community makes no provision for a specific common forestry policy - there have been several actions and instruments in place for which EU Member States are obliged to bring national forest policies in line with EU objectives.

Pursuant to the principle of subsidiarity and the concept of shared responsibility, the European Community contributes to the implementation of Sustainable Forest Management (SFM) and to the multifunctional role of forests (e.g., wood production, protection of biodiversity, protective functions of forest soils and water, socio-economic services) by the means of:

- non-binding policy frameworks, like EU

Tab. 1 - Ranking of importance of main threats to forests in EU Member States (Outcome of an enquiry sent to the members of Standing Forestry Committee (SFC) 6/2007; replies from 22 countries). Legend: $1=$ negligible; $2=$ occasionally a problem at local scale; 3 = regularly a problem at local scale; $4=$ regularly a problem at local scale, but with a tendency of large scale distribution; 5 = serious problem at large scale.

\begin{tabular}{lcccccc}
\hline \multirow{2}{*}{\multicolumn{1}{c}{ Damaging agent }} & \multicolumn{7}{c}{ EUROPE } \\
\cline { 2 - 7 } & Northern & Central & Western & Eastern & Southern & Total \\
\hline Storm / windfall & 2.8 & 3.0 & 3.6 & 2.7 & 1.6 & 2.8 \\
Snow / avalanches & 1.6 & 1.8 & 1.4 & 1.7 & 1.6 & 1.6 \\
Drought & 1.4 & 2.5 & 2.9 & 3.3 & 3.0 & 2.6 \\
Insects & 3.4 & 3.8 & 3.1 & 3.0 & 3.0 & 3.3 \\
Diseases & 3.2 & 2.5 & 2.4 & 2.7 & 2.2 & 2.6 \\
Browsing & 3.4 & 2.5 & 3.0 & 2.7 & 1.8 & 2.7 \\
Domestic animals & 1.0 & 2.3 & 1.3 & 1.7 & 2.4 & 1.7 \\
Invasive species & 1.2 & 1.8 & 2.6 & 2.0 & 1.4 & 1.8 \\
Inappropriate management & 1.2 & 2.0 & 2.0 & 1.3 & 3.0 & 1.7 \\
Illegal logging & 1.4 & 1.8 & 1.1 & 2.7 & 1.2 & 1.5 \\
Pollution & 1.2 & 2.0 & 2.4 & 2.3 & 1.8 & 2.0 \\
Fire & 1.8 & 3.0 & 2.0 & 2.3 & 3.4 & 2.5 \\
\hline
\end{tabular}

Forest Strategy/ Forest Action Plan;

- binding directives, regulations and decisions, like the Birds Directive (Council Directive 79/409/EEC) and Habitats Directive (Council Directive 92/43/EEC), the Forest Focus Regulation (Council Regulation (EC) No 2152/2003) or Rural Development Regulation (Council Regulation (EC) No 1257/1999, replaced by the Council Regulation (EC) No 1698/2005) for which financial support is provided by various funds and financial instruments, like the European Agricultural Rural Development Fund EARDF (Council Regulation (EC) No 1257/1999 and 1698/2005), the Forest Focus scheme or the Financial Instrument for the Environment LIFE+ (Council Regulation (EC) No 1614/2007).

At EU level several efficient and well established measures have been implemented which contribute to the prevention, mitigation and control of forest dieback as shown by Requardt et al. (2007). They are addressed in the following paragraphs.

EU forest related actions are based on the principles as laid down in the EU Forestry Strategy (1998) and the EU Forest Action Plan (2007-2011). With respect to forest damages, the EU Forest Strategy specifically emphasises the need to improve the protection of the Community's forests against atmospheric pollution and against fire. With the principles of the Forestry Strategy still being valid, the Forest Action Plan emphasis the objective of combating forest dieback specifically in its Key Action 9: "Enhance the protection of forests". Further relevant Key Actions in that context are: Key action 6: "Facilitate EU compliance with the obligations on climate change mitigation of the UNFCCC and its Kyoto Protocol and encourage adaptation to the effects of climate change"; Key action 7: "Contribute towards achieving the revised Community biodiversity objectives for 2010 and beyond"; Key action 8: "Work towards a European Forest Monitoring System".

The most important EU instrument for combating forest dieback is the Rural Development Regulation and its financial support by the European Agricultural Fund for Rural Development (EAFRD). These instruments provide support for several prevention and mitigation measures which facilitate towards improving forest stability and forest restoration. The current Rural Development policy is built around a competitiveness axis for agriculture, food and forestry, a land management-environment axis and a quality of life/diversification axis in rural areas. Forestry measures with respect to protection and rehabilitation are part of Axis 2: Improving the environment and the countryside. Of particular importance for the objective of combating forest dieback is the support for restoring forestry potential in forests damaged by natural disasters and fire, and for introducing preventive actions in order to maintain the environmental and economical role of these forests [Code 226]. Within this particular measure many types of specific actions can be supported. Examples are: preventive investments reducing the consequences of forest fires (e.g., forest fire breaks, waterpoints, forest roads, preventive forestry), or investments to restore the forest in its state before the disaster. Other measures such as first afforestation [Code 221 and Code 223], forest-environment payments [Code 225] or payments for Natura 2000 [Code 213 and 323] are rather of indirect relevance towards the objective of combating forest dieback. Rural Development programmes, including the design of the suit- 
able forestry measures, are drafted, implemented, and largely monitored at the national level.

Highly relevant instrument for combating forest dieback has been the expired Forest Focus Regulation (Council Regulation (EC) No 2152/2003). It supported the implementation of forest condition monitoring and forest protection measures against fires during 2003-2006. The new LIFE+ programme (2007-2013) replaces earlier LIFE programmes and the expired Forest Focus Regulation. In principle the scope of the former Forest Focus Regulation activities are incorporated in LIFE+, although it does not provide secured co-financing as in the case of forest condition monitoring under Forest Focus. The monitoring of forest condition as conducted by the joint monitoring programme of ICP Forests/Forest Focus in 2003-2006 or by the European Forest Fire Information System (EFFIS) was regarded by the survey respondents as indispensable to control and detect negative impacts of forest dieback in the short and long term. Collected and evaluated information provides a sound basis for developing and implementing adequate prevention and mitigation measures at different scales. A continuous financial support for harmonised data collection assessing the different causeeffects of forest dieback was seen crucial for maintaining but also improving current forest monitoring systems.

In case of natural disasters, which include large scale forest fires, storms or floods, instruments such as the EU Solidarity Fund (Council Regulation (EC) No 2012/2002) and the Civil Protection Mechanism (Council Decision 2001/792) are becoming increasingly relevant for the provision of fast, effective and flexible emergency financial aid.

In addition to these rather national or regionally focused measures the European Commission actively participates in the international forest regime and in the implementation of various commitments which are relevant to the maintenance of forest ecosystem health and vitality (EU and the International Forest Regime, see: http://ec.europa.eu/agriculture/fore/various/international_en.htm). The role of the EU to influence, support and implement international commitments and resolutions as formulated by global processes (e.g., the UNFCCC, CBD and CCD) or by regional processes such as the Ministerial Conference on the Protection in Europe (MCPFE) is of high importance and needs to be strengthened in future. Joint coordination of various international processes combined in strategic documents of the EC, like the Forest Action Plan, are important steps for a holistic action at European level. By taking different objectives and requirements of international forest related processes into account, a common framework for forest protection and maintenance including the particular objective of combating forest dieback, should be formulated at EU level. The new Forest Action Plan established for the period of 2007 to 2011 could provide a good basis for such common framework in future.

\section{Possibilities to combat different causes offorest dieback}

From the perspective of different causes of forest dieback it can be concluded that not all damaging agents can be targeted equally by EU measures.

Climate change is widely regarded as the main driving force of different cause-effects on forest dieback both now and undoubtedly in the future. Climate change will have pronounced impacts on land use regimes, forest health and vitality, and the sustainable supply of goods and services for the population (IPCC 2007). Changing environmental conditions induced by climate change will increase the vulnerability of European forests and result in adaptation processes (EEA 2005). Although forests have responded to climate change throughout their evolutionary history, a primary concern for forest ecosystems is the rapid rate of change. Also of concern is that the incidence, frequency and intensity of several other damaging agents like drought, heavy precipitations, fire, storms, insects and diseases are strongly linked to the impacts of climate change.

There are several EU activities ongoing targeting towards mitigating and combating climate change and its effects at different scales. With respect to European forests, challenges are seen in incorporating the different cause-effects of climate change on forest health and vitality into effective instruments and measures. Future risks for forest ecosystem health and vitality caused by climate change are considered only to a minor extent in forest management programmes. Future instruments will need to embrace more strongly mitigation and control measures besides already existing prevention activities.

Fire is the most extensively covered damaging agent within EU funds/financial instruments. There are several EU measures which support fire prevention, mitigation and control (see Tab. 2). Forest Focus funds were available for monitoring forest fires and partly also for prevention activities. In particular, the European Forest Fire Information System (EFFIS) has become an important monitoring tool addressing both pre-fire and

Tab. 2 - EU funds and their relevance for a protection strategy, described by the aspects prevention, mitigation and control.

\begin{tabular}{|c|c|c|c|c|}
\hline \multirow{2}{*}{ Financial instrument } & \multirow{2}{*}{ Prevention } & \multirow{2}{*}{ Mitigation } & \multicolumn{2}{|c|}{ Control } \\
\hline & & & Monitoring & Management \\
\hline Cohesion Fund & - & $\mathrm{x}$ (pollution) & - & - \\
\hline European Regional Development Fund & $\begin{array}{l}\text { x (natural risks) } \\
\text { x (fire) } \\
\text { x (pollution) }\end{array}$ & $\begin{array}{l}\text { x (natural risks) } \\
\text { x (fire) } \\
\text { x (pollution) }\end{array}$ & - & $\begin{array}{l}\text { x (natural risks) } \\
\text { x (fire) } \\
\text { x (pollution) }\end{array}$ \\
\hline European Union Solidarity Fund & - & $\begin{array}{l}\text { x (fire) } \\
\text { x (disasters) }\end{array}$ & - & - \\
\hline Life & $\mathrm{x}$ (fire) & - & $\begin{array}{l}\mathrm{x} \text { (pollution) } \\
\mathrm{x} \text { (fire) }\end{array}$ & - \\
\hline Civil Protection mechanism & $\mathrm{x}$ (disasters) & $\mathrm{x}$ (disasters) & - & \\
\hline Forest Focus 2003-2006 & $\mathrm{x}$ (fire) & - & $\begin{array}{l}\text { x (pollution) } \\
\text { x (fire) }\end{array}$ & - \\
\hline $\begin{array}{l}\text { Rural Development Regulation - } \\
\text { Agri-Environmental Measures }\end{array}$ & $\begin{array}{l}\text { x (natural hazards) } \\
\text { x (fire) }\end{array}$ & - & - & - \\
\hline Rural Development Regulation - EAGGF & $\begin{array}{l}\mathrm{x} \text { (natural disasters) } \\
\mathrm{x} \text { (fire) }\end{array}$ & $\begin{array}{l}\mathrm{x} \text { (natural disasters) } \\
\mathrm{x} \text { (fire) }\end{array}$ & - & $\begin{array}{l}\mathrm{x} \text { (forest improvement) } \\
\mathrm{x} \text { (restoration) }\end{array}$ \\
\hline Rural Development Regulation - EAFRD & $\begin{array}{l}\mathrm{x} \text { (natural disasters) } \\
\mathrm{x} \text { (fire) }\end{array}$ & $\begin{array}{l}\mathrm{x} \text { (natural disasters) } \\
\mathrm{x} \text { (fire) }\end{array}$ & - & $\begin{array}{l}\mathrm{x} \text { (forest improvement) } \\
\mathrm{x} \text { (restoration) }\end{array}$ \\
\hline
\end{tabular}


post-fire conditions. In terms of prevention the EU addresses a variation of targeted forest fire measures by different financial instruments, like the European Regional Development Fund, the European Agricultural Rural Development Fund (EARDF) or LIFE+. Improvements are seen in enhancing the coordination and coherency between the different existing fire prevention and restoration measures thus leading to an increase in their effectiveness.

For storms there is a set of EC funds/financial instruments available, which support the prevention and mitigation of storm damages. An example is the European Agricultural Rural Development Fund (EARDF) which gives support to re-forestation measures. The major emphasis of EC instruments for storms now and in the future should target towards the mitigation of disastrous, large scale storm events. Prevention measures have to aim at increasing stand stability and the propagation of site adapted tree species and are thus restricted to long term processes and risk reduction. To mitigate the excessive availability of timber after large scale storm events and the resulting changes of timber assortments, the EU may explore options for regulatory market mechanisms or support to compensate payment schemes.

The EU forest related policy has only limited possibilities of support in terms of prevention and mitigation measures when it comes to impacts of air pollution on forest health and vitality. Priorities are set on supporting forest condition monitoring and assessing different cause-effects between depositions of air pollutants and forest dieback. The importance of monitoring air pollution effects on forests as it is conducted under the UNECE ICP Forests scheme is widely recognised (see ICP Forests 2006). It was financially supported by the EC Forest Focus regulation during 2003-2006. As the scope of the former Forest Focus Regulation is reflected in LIFE+, a co-financing mechanism for forest monitoring on a voluntary basis is provided in 2007-2013. A continuous financial support after 2013 should be targeted in order to allow for the collection of data as it has been done under the Forest Focus scheme. This is especially important as such data is needed for various international reporting obligations and research activities within and beyond the forest sector.

According to the MCPFE (MCPFE 2003, MCPFE 2007), about $2.7 \%$ of the forest area in the MCPFE region (excluding the Russian Federation) are adversely affected by insects and diseases. In contrast to transboundary air pollution effects, impacts caused by insects and diseases generally have a more punctual appearance in the form of outbreaks. According to the EEA 2005, insects and diseases are likely to react to long-term environmental change processes such as those

Box 2 - EU communications, directives and regulations cited.

- COM (2004) 621 final: Proposal for a Regulation of the European Parliament and of the Council concerning the Financial Instrument for the Environment (LIFE+)

- COM (2006) 302 final: Communication from the Commission to the Council and the European Parliament of 15 June 2006 on an EU Forest Action Plan

- Commission Regulation (EC) No 2355/2002 of 27 December 2002 amending Commission Regulation (EC) No 438/2001 laying down detailed rules for the implementation of Council Regulation (EC) No 1260/1999 as regards the management and control systems for assistance granted under the Structural Funds

- Council 2004, Preventing Forest Fires - Report to Committee on the Environment, Agriculture and Local and Regional Affairs of the Council of Europe

- Council Decision 89/367/EEC in May 1989 setting up a Standing Forestry Committee

- Council Decision of 23 October 2001 establishing a Community mechanism to facilitate reinforced cooperation in civil protection assistance

- Council Directive 79/409/EEC of 2 April 1979 on the conservation of wild birds

- Council Directive 92/43/EEC of 21 May 1992 on the conservation of natural habitats and of wild fauna and flora

- Council Regulation (EC) No 1257/1999 of 17 May 1999 on support for rural development from the European Agricultural Guidance and Guarantee Fund (EAGGF) and amending and repealing certain Regulations

- Council Regulation (EC) No 1260/1999 of 21 June 1999 laying down general provisions on the Structural Funds

- Council Regulation (EC) No 1698/2005 of 20 September 2005 on support for rural development by the European Agricultural Fund for Rural Development (EAFRD)

- Council Regulation (EC) No 2012/2002 of 11 November 2002 establishing the European Union Solidarity Fund (EUSF)

- Council Regulation (EEC) No 1973/92 of 21 May 1992 establishing a financial instrument for the environment (LIFE)

- Council Regulation (EEC) No 2158/92 of 23 July 1992 on protection of the Community's forests against fire (OJ L217, 31. 7. 1992)

- Council Regulation (EEC) No 3528/86 of 17 November 1986 on the protection of the Community's forests against atmospheric pollution

- Council Resolution of 15 th of December 1998 on a Forestry Strategy for the European Union (1999/C 56/01)

- Directive 2000/60/EC of the European Parliament and of the Council of 23 October 2000 establishing a framework for Community action in the field of water policy.

- Regulation (EC) No 1655/2000 of the European Parliament and of the Council of 17 July 2000 concerning the Financial Instrument for the Environment (LIFE)

- Regulation (EC) No 1682/2004 of the European Parliament and of the Council of 15 September 2004 amending Regulation (EC) No 1655/2000 concerning the Financial Instrument for the Environment (LIFE)

- Regulation (EC) No 2152/2003 of the European Parliament and of the Council of 17 November 2003 concerning monitoring of forests and environmental interactions in the Community (Forest Focus)

- Regulation (EC) No 614/2007 of the European Parliament and of the Council of 23 May 2007 concerning the Financial Instrument for the Environment (LIFE+)

caused by climate change. Extreme weather conditions such as heavy storms and/or drought can elevate the risk of mass propagations, e.g., as of bark beetles (see ICP Forests 2004). The EU contributes to the prevention and mitigation of damages caused by insects and diseases in supporting reforestation and restoration of forestry potential and the introduction of preventive actions by the means of the Rural Development Regulation. Improvements are seen in the collection of more representative data about the abundance and occurrence of negative impacts due to different insects and diseases in different regions. Insect damages have been given the highest ranking by the respondents to the feasibility study's survey (see Tab. 1). As- sessments on the relative importance of the impacts of insects and diseases on forest health and vitality and therefore on forest economy should be developed further. Contribution by the EU to support and improve monitoring activities on insects and diseases is regarded as crucial.

Alien invasive species can cause considerable damages although often affecting forests more at regional or local scale. EC directives incorporate protective measures linked to the import or introduction of harmful organisms and products. As this may seem sufficient in terms of prevention, it may become necessary to look in more detail into the effectiveness of these measures. In this respect ongoing research activities will 
need to be closely monitored as they may yield substantial information and knowledge on alien invasive species. The provision of support for effective mitigation measures, which allow to control the spread of already established, persistent species should be of particular concern.

According to the MCPFE (2007) only 3\% of the forests (excluding the Russian Federation) are facing damages by wildlife. However, the quality and provision of the data was limited, making an estimate of damages caused by wildlife and/or livestock in the MCPFE region difficult. Nevertheless it can be concluded that grazing and browsing cause considerable damages to many forests in Europe. This is also clearly reflected by the survey conducted in the scope of the feasibility study, where damage by wildlife was assigned the third highest rank among all damaging agents. Extensive and costly measures have to be taken for the protection of regeneration and afforestation areas. Mitigation of damages through the active reduction of game populations and fencing are often measures which are addressed at local or regional level thus giving the EC limited possibilities of engagement. The Rural Development Regulation may provide support for protection measures linked to reforestation and afforestation activities. In terms of control the EC could promote effective monitoring of damages by wildlife and livestock and the improvement of data quality.

\section{Conclusion}

At the EU level several efficient and well established measures are already developed and implemented, which contribute to the prevention, mitigation and control of forest dieback. In the wake of current and the predicted development of environmental pressures, in particularly that of climate change, swift actions will become necessary at EU level in order to combat forest dieback and its repercussions effectively. One major challenge will be to incorporate future patterns of forest dieback, into existing, amended or new measures. Therefore existing measures will need to be revisited and in cases further developed in order to:

1. increase synergy effects between individual instruments,

2. make the instruments more transparent to the full range of potential stakeholders and beneficiaries, and

3. improve the communication between the different actors involved.

Additional measures may become necessary to support or enhance existing ones, whereas overlaps with well established and implemented measures should be minimised. Only a well coordinated and balanced set of measures addressing the prevention, mitigation and control of the multiple causes of forest dieback at different scales will allow to strengthen the EU in maintaining and enhancing the multiple, beneficial functions of forests and their contribution to the quality of life.

\section{Acknowledgements}

The authors especially like to thank Gerben Janse (EFI), Robert Mavsar (EFI), Markku Husso (EFI), Jutta Poker (Hamburg) and Thomas W. Schneider (Institute for World Forestry) for their tremendous input to this study. They would also like to thank Ernst Schulte and Zoltan Rakonczay from DG ENV for their valuable advice and assistance, thus allowing implementing the study "Means of combating forest dieback in the European Union" successfully. Furthermore the authors' thanks goes to the members of the Standing Forestry Committee (SFC) and the Advisory Group on Forestry and Cork (AGFC) for their interest, input and feed- back.

\section{References}

EEA (2005). Vulnerability and adaptation to climate change in Europe, European Environmental Agency, Technical Report 7/2005, pp. 79.

ICP Forests (2004). The condition of forests in Europe, 2004 Executive Report. Federal Research Centre for Forestry and Forest Products (BFH), United Nations Economic Commission for Europe, Geneva, Switzerland, pp. 36.

ICP Forests (2006). The condition of forests in Europe, 2006 Executive Report. Federal Research Centre for Forestry and Forest Products (BFH), United Nations Economic Commission for Europe, Geneva, Switzerland, pp. 33.

IPCC (2007). Summary for Policymakers of the Synthesis Report of the IPCC Fourth Assessment Report. [online] URL: http://arch.rivm.nl/env/int/ ipcc/pagesmedia/AR4SYRSPMapprv4.pdf

MCPFE (2003). State of Europe's forests 2003. The MCPFE Report on Sustainable Forest Management in Europe, pp. 114.

MCPFE (2007). State of Europe's forests 2007. The MCPFE report on Sustainable Forest Management in Europe, Jointly prepared by the MCPFE Liaison Unit Warsaw, UNECE and FAO, Warsaw, Poland, pp. 263.

Requardt A, Köhl M, Schuck A, Poker J, Janse G, Masvar R, Päivinen R (2007). Feasibility study on means of combating forest dieback in the European Union. EC DG ENV Contract (070102110004/2006/449050/MAR/B1), Brussels, Belgium, pp. $79+$ Annex I, II, III. [online] URL: http://ec.europa.eu/environment/forests/fpolicies.htm

UNECE/FAO (2000). Forest resources of Europe, CIS, North America, Australia, Japan and New Zealand (TBFRA 2000). Main report, UNECE/FAO Contribution to the Global Forest Resources Assessment 2000, United Nations, New York and Geneva, pp. 445. 